\title{
Screening of selected plant-derived extracts for their antimicrobial activity against oral pathogens
}

\begin{abstract}
Background: Dental caries is a major public health concern that affects the populations of many countries worldwide. In this paper, we screened twenty-four plant-derived extracts for their antimicrobial activity against a representative panel of cariogenic bacteria.

Methods: The leaves of each species were dried, powdered and sequentially extracted with $n$-hexane, dichloromethane and methanol under Sonication for $5 \mathrm{~min}$. The minimum inhibitory concentration (MIC) values of the resulting extracts were determined by using the broth micro dilution method in 96-well micro plates. Chlorhexidine was used as positive control. The chemical composition of the most active extract was determined by gas chromatography - mass spectrometry (GC-MS).
\end{abstract}

Results: The $n$-hexane extract of $P$. neochilus (PN-Hex) afforded the lowest MIC values against $S$. mitis (MIC $=31.2 \mu \mathrm{g} / \mathrm{mL}$ ), $S$. mutans (MIC=31.2 $\mu \mathrm{g} / \mathrm{mL}$ ), $S$. sanguinis $(\mathrm{MIC}=31.2 \mu \mathrm{g} / \mathrm{mL})$, S. salivarus $(\mathrm{MIC}=62.5 \mu \mathrm{g} / \mathrm{mL})$, S. sobrinus $(\mathrm{MIC}=62.5 \mu \mathrm{g} /$ $\mathrm{mL})$, E. faecalis $(\mathrm{MIC}=62.5 \mu \mathrm{g} / \mathrm{mL})$ and L. casei $(\mathrm{MIC}=250 \mu \mathrm{g} / \mathrm{mL})$. GC-MS analysis of this extract revealed that spathulenol $(46.1 \%)$, trans-caryophyllene $(19.0 \%)$, caryophyllene oxide $(10.7 \%)$ and germacrene D $(7.8 \%)$ were the major constituents in PN-Hex.

Conclusion: The $n$-hexane extract of $P$. neochilus (PN-Hex) displays promising antimicrobial activity against some cariogenic bacteria. Our results suggest that this extract might be promising for the development of new oral care products.
Volume 6 Issue 3 - 2017

\author{
Herbert J Dias,' Tatiana MVieira,' Carlos \\ E Carvalho, ${ }^{2}$ Gabriela P Aguiar, ${ }^{2}$ Kamila AL \\ Wakabayashi, ${ }^{2}$ Izabel CC Turatti, ${ }^{3}$ Guilherme \\ BWillrich,' Milton Groppo, ${ }^{4}$ Wilson R \\ Cunha, ${ }^{2}$ Carlos HG Martins, ${ }^{2}$ Antonio crotti \\ 'Department of Chemistry, University of São Paulo, Brazil \\ ${ }^{2}$ Nucleus of Research in Exact and Technological Sciences, \\ University of Franca, Brazil \\ ${ }^{3}$ Departamento de Física e Química, University of São Paulo, \\ Brazil \\ ${ }^{4}$ Department of Biology, University of São Paulo, Brazil
}

Correspondence: Antônio EM Crotti, Departamento de Química, Faculdade de Filosofia, Ciências e Letras de Ribeirão Preto, Universidade de São Paulo, Av. Bandeirantes, 3900, Monte Alegre, CEP |4040-90 I Ribeirão Preto, SP, Brazil,Tel +55 16 3515 3747, Fax 551635154838 , Email millercrotti@ffclrp.usp.br

Received: January 27, 2017| Published: April 04, 2017

Keywords: oral pathogens, antibacterial activity, plectranthus neochilus, streptococcus mutans, dental caries

\section{Abbreviations: GC-MS, gas chromatography-mass} spectrometry; CHD, chlorhexidine

\section{Introduction}

Dental caries and other periodontal diseases are a major public health concern that affects the populations of many countries worldwide. ${ }^{1}$ These pathologies are associated with acidogenic and aciduric bacteria that adhere to the tooth surface as a structurally and functionally organized biofilm (dental plaque) and can destroy dental hard tissues. ${ }^{2}$ These bacteria can reach the bloodstream and trigger other diseases such as endocarditis, brain abscesses, throat infections, respiratory and gastrointestinal system infections, and bacteraemia. ${ }^{3,4}$

The most efficient way to prevent caries and other periodontal diseases is to remove the biofilm by brushing and flossing the teeth and conducting periodic dental cleaning or prophylaxis. ${ }^{5}$ Unfortunately, most people fail to maintain a sufficient level of oral control through mechanical removal only, which has called for the use of oral products containing antimicrobial ingredients as a complementary measure to diminish biofilm formation on the tooth surface. ${ }^{6}$ Therefore, the use of chemicals as a complementary measure to diminish the tooth surface biofilm is necessary and has proven to be a valuable tool to diminish the tooth surface biofilm. ${ }^{7,8}$ Currently, chlorhexidine has been the most effective antiplaque agent tested to date; but some reversible local side effects have led dentists to recommend its use for short periods only. ${ }^{9}$ Several other antimicrobial agents including fluorides, phenol derivatives, ampicillin, erythromycin, penicillin, tetracycline, and vancomycin can also inhibit bacterial growth. Nevertheless, excessive use of these chemicals can disturb the oral and intestinal flora and cause microorganism susceptibility, vomiting, diarrhea, and tooth staining. ${ }^{9}$ To find an alternative to the substances currently employed to prevent caries and to control plaques, researchers have investigated the antimicrobial activities of natural products and their potential as new chemotherapeutic agents for incorporation in dental products. ${ }^{10}$

As part of our ongoing research on the antibacterial activities of natural products as potential leads for use in dental products, ${ }^{1,11,12}$ this paper reports on the evaluation of the antibacterial activity of twentyfour plant-derived extracts against a panel of oral pathogenic bacteria.

\section{Materials and methods}

\section{Plant material and extraction}

The plants used in this study were collected in May 2010 at "Sítio 13 de Maio" (20o26'S 47o27'W 977m) near Franca, State of São Paulo, Brazil. Voucher specimens of each species were deposited at the Herbarium of Departamento de Biologia, Faculdade de Filosofia, Ciências e Letras de Ribeirão Preto, Universidade de São Paulo, São Paulo, Brazil (Herbarium SPFR), as shown in Table 1.

Firstly, fresh leaves of each species were submitted to hydrodistillation in a Clevenger-type apparatus for $3 \mathrm{~h}$, as previously reported. ${ }^{13,17}$ After the essential oil extraction, the leaves of each species were dried at room temperature, powdered and sequentially extracted with $n$-hexane, dichloromethane and methanol ( $1 \mathrm{~mL} / 10 \mathrm{mg}$ of powder) under Sonication for $5 \mathrm{~min}$. Samples were concentrated under reduced pressure to result in the $n$-hexane (HEX), dichloromethane (DCM) and methanol $(\mathrm{MeOH})$ extracts.

\section{Antimicrobial assays}

The minimum inhibitory concentration (MIC) values of the plantderived extracts were determined by using the broth microdilution 
method in 96-well microplates. ${ }^{18}$ The following standard strains from the ATCC were used: Enterococcus faecalis (ATCC 4082), Streptococcus salivarius (ATCC 25975), Streptococcus sobrinus (ATCC 33478), Streptococcus mutans (ATCC 25175), Streptococcus mitis (ATCC 49456), Streptococcus sanguinis (ATCC 10556) and Lactobacillus casei (ATCC 11578). Individual $24 \mathrm{~h}$ colonies from blood agar (Difco Labs, Detroit, Mich, USA) were suspended in $10.0 \mathrm{~mL}$ of tryptic soy broth (Difco). The standardization of each microorganism suspension was carried out using spectrophotometer (Femto, São Paulo, Brazil) at wavelength $(\lambda)$ of $625 \mathrm{~nm}$ to match the transmittance of 81 , equivalent to $0.5 \mathrm{McFarland}$ scale $(1.5 \times 108$ $\mathrm{CFU} / \mathrm{mL}$ ) and dilution at final concentration of the $5 \times 105 \mathrm{CFU} /$ $\mathrm{mL}$. The samples were dissolved in DMSO (Merck, Darmstadt, Germany) at $4 \mathrm{mg} / \mathrm{mL}$, and they were then diluted in tryptic soy broth (Difco) so that concentrations in the range of 3.9 to $4000 \mu \mathrm{g} / \mathrm{mL}$ were achieved. After dilutions, the DMSO concentrations were between
$4 \%$ and $0.0039 \%(\mathrm{v} / \mathrm{v})$. Three inoculated wells containing DMSO at concentrations ranging from $4 \%$ to $1 \%$ were used as negative controls. One inoculated well was included, so as to control the adequacy of the broth for organism growth. One non-inoculated well free of antimicrobial agent was also included to ensure medium sterility. Two-fold serial dilutions of chlorhexidine digluconate (Sigma) were made in tryptic soy broth (Difco) to achieve concentrations ranging from 59 to $0.115 \mu \mathrm{g} / \mathrm{mL}$. These dilutions were used as positive control. The microplates (96 well) were sealed with parafilm and incubated at $37^{\circ} \mathbf{C}$ for $24 \mathrm{~h}$. After that, $30 \mathrm{~mL}$ of $0.02 \%$ reassuring (Sigma, St. Louis, MO, USA) aqueous solution was poured in each microplate reservoir, to indicate the microorganism viability. ${ }^{19}$ The MIC (i.e., the lowest concentration of a sample capable of inhibiting microorganism growth) was determined as the lowest concentration of the extracts capable of preventing a colour change of the resazurin solution. ${ }^{19}$ Three replicates were conducted for each microorganism.

Table I Plant species selected for this study and their respective voucher number and code

\begin{tabular}{lllc}
\hline Plant & \multicolumn{2}{c}{ Family } & C Code Voucher number \\
\hline Artemisia absinthum Vill. & Asteraceae & AA & 12417 \\
Bidens sulphurea(Cav.) Sch. Bip. & Asteraceae & BS & 12020 \\
Ocimum gratissimumL. & Lamiaceae & OG & 12420 \\
Plectranthus neochilusSchltr. & Lamiaceae & PN & 12323 \\
Syzygium aromaticum(L.) Merr. \& L.M.Perry & Myrtaceae & SA & 12418 \\
Stachytarpheta cayennensis (Rich.) Vahl. & Verbenaceae & SC & 10005 \\
Tagetes erecta L. & Asteraceae & TE & 10009 \\
Tetradenia riparia (Hochst.) Codd. & Lamiaceae & TR & 12421 \\
\hline
\end{tabular}

Table 2 In vitro antibacterial activity (MIC) of the selected plant-derived extracts against oral pathogens

\begin{tabular}{|c|c|c|c|c|c|c|c|}
\hline & S. mitis & S. mutans & S. sanguinis & S. salivarus & S. sobrinus & E. faecalis & L. casei \\
\hline AA-Hex & $\geq 4000$ & 4000 & 4000 & 4000 & $\geq 4000$ & $\geq 4000$ & $\geq 4000$ \\
\hline AA-DCM & 4000 & $\geq 4000$ & $\geq 4000$ & $\geq 4000$ & $\geq 4000$ & $\geq 4000$ & 4000 \\
\hline $\mathrm{AA}-\mathrm{MeOH}$ & 4000 & 4000 & 4000 & 4000 & 4000 & $\geq 4000$ & 4000 \\
\hline BS-Hex & 2000 & 4000 & 4000 & 4000 & 4000 & 4000 & 4000 \\
\hline BS-DCM & 2000 & 4000 & 4000 & 4000 & 4000 & $\geq 4000$ & 4000 \\
\hline $\mathrm{BS}-\mathrm{MeOH}$ & 1000 & 2000 & 1000 & 2000 & 2000 & $\geq 4000$ & 4000 \\
\hline OG-Hex & $\geq 4000$ & $\geq 4000$ & $\geq 4000$ & $\geq 4000$ & $\geq 4000$ & $\geq 4000$ & $\geq 4000$ \\
\hline OG-DCM & $\geq 4000$ & $\geq 4000$ & $\geq 4000$ & $\geq 4000$ & $\geq 4000$ & $\geq 4000$ & $\geq 4000$ \\
\hline OG-MeOH & 4000 & $\geq 4000$ & 2000 & 4000 & 4000 & $\geq 4000$ & $\geq 4000$ \\
\hline PN-Hex & 31.2 & 31.2 & 31.2 & 62.5 & 62.5 & 62.5 & 250 \\
\hline PN-DCM & 62.5 & 62.5 & 62.5 & 250 & 250 & 250 & 1000 \\
\hline $\mathrm{PN}-\mathrm{MeOH}$ & 62.5 & 500 & 125 & 1000 & 1000 & 1000 & 4000 \\
\hline SA-Hex & 2000 & $\geq 4000$ & 4000 & 4000 & 4000 & 1000 & $\geq 4000$ \\
\hline SA-DCM & 2000 & 4000 & 4000 & 4000 & 4000 & $\geq 4000$ & 500 \\
\hline SA-MeOH & $\geq 4000$ & 2000 & $\geq 4000$ & $\geq 4000$ & 2000 & $\geq 4000$ & $\geq 4000$ \\
\hline SC-Hex & 250 & 125 & 500 & 4000 & 250 & $\geq 4000$ & 4000 \\
\hline SC-DCM & 250 & 250 & 500 & 2000 & 250 & $\geq 4000$ & $\geq 4000$ \\
\hline $\mathrm{SC}-\mathrm{MeOH}$ & 250 & 125 & 500 & 4000 & 250 & $\geq 4000$ & 4000 \\
\hline TE-Hex & 1000 & 4000 & 4000 & 4000 & 4000 & $\geq 4000$ & 4000 \\
\hline TE-DCM & 2000 & 4000 & 4000 & 4000 & 4000 & 4000 & 4000 \\
\hline TE-MeOH & 2000 & 4000 & 4000 & 2000 & 4000 & 4000 & 2000 \\
\hline TR-Hex & 125 & 62.5 & 1000 & 4000 & 250 & 4000 & 1000 \\
\hline TR-DCM & 125 & 62.5 & 1000 & 4000 & 250 & 4000 & 1000 \\
\hline TR-MeOH & 2000 & 4000 & 2000 & 2000 & 2000 & 4000 & 2000 \\
\hline $\mathrm{CHD}$ & 14.7 & 1.8 & 7.3 & 7.3 & 1.8 & 14.7 & 3.6 \\
\hline
\end{tabular}

\section{Gas chromatography-mass spectrometry analysis}

Gas chromatography-mass spectrometry (GC-MS) analysis was carried out on a ShimadzuQP2010 Plus (Shimadzu Corporation, Kyoto, Japan) system equipped with an AOC-20i autosampler. The column consisted of Rtx-5MS (Restek Co., Bellefonte, PA, USA) fused-silica capillary (length $=30 \mathrm{~m}$, i.d. $=0.25 \mathrm{~mm}$, and film thickness $=0.25 \mu \mathrm{m})$. Helium $(99.999 \%)$ at a constant flow of $1.0 \mathrm{~mL} / \mathrm{min}$ was the carrier gas. The injection volume was $0.1 \mu \mathrm{L}$ (split ratio of 1:10). The injector and the ion source temperatures were set at 240 and 280 ${ }^{\circ} \mathrm{C}$, respectively. The oven temperature was programmed to increase from $60{ }^{\circ} \mathrm{C}$ to $240{ }^{\circ} \mathrm{C}$ at $3{ }^{\circ} \mathrm{C} / \mathrm{min}$, then hold at $240^{\circ} \mathrm{C}$ for $20 \mathrm{~min}$. The 
electron ionization (EI-MS) mode at $70 \mathrm{eV}$ was employed. The mass spectra were registered with a scan interval of $0.5 \mathrm{~s}$ in the mass range of 40 to $600 \mathrm{Da}$.

The chemical components of the $n$-hexane extract of Plectranthus neochilus were identified on the basis of their retention indices relative to a homologous series of $n$-alkanes (C8-C40) on a Rtx-5MS capillary column under the same operating conditions and computer matching with the Wiley 7, NIST 08 and FFNSC 1.2 spectral libraries of the GC-MS system, as well as by comparison of their mass spectra with those reported in the literature. ${ }^{20}$

Table 3 Chemical composition of the n-hexane extract of Plectranthus neochilus (PN-Hex)

\begin{tabular}{|c|c|c|c|c|c|}
\hline Compound & RT & $\mathbf{R} \mathbf{I}_{\exp }$ & $\mathbf{R} \mathbf{I}_{\text {lit }}$ & RA \% & Identification \\
\hline Trans-caryophyllene & 23.84 & 1416 & 1418 & 19.0 & RI, MS, Co \\
\hline Alloaromadendrene & 25.52 & 1457 & $|46|$ & 0.7 & $\mathrm{RI}, \mathrm{MS}$ \\
\hline Germacrene D & 26.47 & 1480 & 1480 & 7.8 & $\mathrm{RI}, \mathrm{MS}$ \\
\hline a-amorphene & 26.63 & 1484 & 1485 & 0.6 & $\mathrm{RI}, \mathrm{MS}$ \\
\hline Valencene & 26.88 & 1490 & |49| & 0.2 & $\mathrm{RI}, \mathrm{MS}$ \\
\hline g-cadinene & 27.76 & 1512 & 1512 & 0.3 & RI, MS \\
\hline Caryophyllene oxide & 30.12 & 1572 & 1573 & 10.7 & RI, MS, Co \\
\hline Sphatulenol & 30.24 & 1575 & 1576 & 46.1 & RI, MS \\
\hline Neophytadiene & 39.71 & 1834 & 1836 & 3.2 & $\mathrm{RI}, \mathrm{MS}$ \\
\hline Ledane & 40.63 & |84| & 1844 & 3.4 & $\mathrm{RI}, \mathrm{MS}$ \\
\hline trans-phytol & 43.36 & 1943 & 1949 & 3.0 & $\mathrm{RI}, \mathrm{MS}$ \\
\hline Squalene & 53.96 & 2784 & 2790 & 1.7 & RI, MS \\
\hline a-tocopherol & 59.08 & 305 & 3100 & 3.3 & RI, MS \\
\hline Total identified & & & & 99.9 & \\
\hline
\end{tabular}

\section{Results and discussion}

This work investigated the antimicrobial activity of twentyfour extracts from the leaves of eight herbaceous or arbustive plant species against a representative panel of cariogenic bacterial strains. These species were selected on the basis of reports on their uses as antimicrobial in the folk medicine or previous studies on their antibacterial or antifungal activities. . $11,12,21,22^{2}$

The antimicrobial activity was evaluated in terms of their minimum inhibitory concentration (MIC). Classification of the antibacterial activity was based on MIC values, as follows: MIC $<100 \mathrm{mg} / \mathrm{mL}$, good; $100<\mathrm{MIC}<500 \mathrm{mg} / \mathrm{mL}$, moderate; $500<\mathrm{MIC}<1000 \mathrm{mg} /$ $\mathrm{mL}$, weak; MIC $>1000 \mathrm{mg} / \mathrm{mL}$, inactive. ${ }^{23}$ Most of the evaluated extracts were inactive or weakly active against the panel of selected oral bacteria (Table 2). The $n$-hexane extract of P. neochilus (PNHex) afforded the lowest MIC values against $S$. mitis (MIC $=31.2 \mu \mathrm{g}$ / $\mathrm{mL}), S$. mutans $(\mathrm{MIC}=31.2 \mu \mathrm{g} / \mathrm{mL}), S$. sanguinis $(\mathrm{MIC}=31.2 \mu \mathrm{g} /$ $\mathrm{mL})$, S. salivarus $(\mathrm{MIC}=62.5 \mu \mathrm{g} / \mathrm{mL})$, S. sobrinus $(\mathrm{MIC}=62.5 \mu \mathrm{g} /$ $\mathrm{mL})$, E. faecalis $(\mathrm{MIC}=62.5 \mu \mathrm{g} / \mathrm{mL})$ and L. casei $(\mathrm{MIC}=250 \mu \mathrm{g} / \mathrm{mL})$. The dichlorometane (PN-DCM) and methanol (PN-MeOH) extracts of $P$. neochilus was also active against $S$. mitis $(\mathrm{MIC}=62.5 \mu \mathrm{g} / \mathrm{mL})$. Moreover, the dichlorometane extract of $P$. neochilus (PN-DCM) and the $n$-hexane and dichloromethane extracts of Tetradenia riparia (TRHex and TR-DCM, respectively) were also active against $S$. mutans $((\mathrm{MIC}=62.5 \mu \mathrm{g} / \mathrm{mL})$. The activity of PN-Hex, PN-DCM, TRHex and TR-DCM extracts against $S$. mutans is an interesting result because very few natural compounds can inhibit these bacteria, one of the primary causative agents of dental caries. ${ }^{24}$ All the extracts of Stachytarpheta cayenensis displayed moderate activity against $S$. mitis, $S$. mutans, $S$. sanguinis and $S$. salivarus. None of the tested EOs was significantly active against Lactobacillus casei (Table 2).

The chemical composition of PN-Hex, the most active extract against the selected panel of cariogenic bacteria was determined by gas chromatography-mass spectrometry (GC-MS). A total of thirteen compounds were detected, with predominance of sesquiterpenes $(88.8$ $\%$ ), as given in Table 3. The major constituents were identified as being spathulenol (46.1\%), trans-caryophyllene (19.0\%), caryophyllene oxide $(10.7 \%)$ and germacrene D (7.8 \%). Trans-caryophyllene, caryophyllene oxide and germacrene D were previously detected in the essential oil from the leaves of P. neochilus. ${ }^{1,15}$

Crevelin and co-workers demonstrated that trans-caryophyllene and caryophyllene oxide, when tested alone against the same selected cariogenic bacteria as we used here, displayed MIC values higher than $4000 \mu \mathrm{g} / \mathrm{mL}){ }^{1}$ Aguiar and co-workers reported germacrene $\mathrm{D}$ as being the major constituent in the essential oil from the leaves of Bidens sulphurea, which displayed moderate activity against Streptococcus mutans (MIC $=250 \mu \mathrm{g} / \mathrm{mL}$ ) and significant activity against Streptococcus mitis (MIC $=31.2 \mu \mathrm{g} / \mathrm{mL}) .{ }^{11}$ On the other hand, although the antimicrobial activity of spathulenol against Staphylococcus aureus and S. epidermidis was previously reported, ${ }^{25}$ it has been identified only as minor constituent in some essential oils with antimicrobial activity against cariogenic bacteria. ${ }^{12}$

Non-polar compounds are usually assumed to diffuse across the cell membranes easily and to kill microorganisms by effecting the metabolic pathways or organelles of the bacteria. Additionally, these compounds could interact with the bacteria membrane and elicit drastic physiological changes, causing loss of membrane permeability, which ultimately leads to cell death. ${ }^{1}$ This hypothesis is consistent with the fact that of the $n$-hexane and dichloromethane extracts of $P$. neochilus, $S$. cayennensis and T. riparia were the most active against the selected panel of cariogenic bacteria, whereas most of the methanol extracts were inactive against these bacteria. In the case of PN-Hex, which was the most active extract against the cariogenic bacteria tested in this study, the sesquiterpenes spathulenol and germacrene D could be the responsible for its activity. Alternatively, the antimicrobial activity of PN-Hex may also be related to the other minor chemical constituents identified in the oil, which may underlie or even increase the activity of the major chemical constituents of PN-Hex.

\section{Conclusion}

The $n$-hexane extract of $P$. neochilus (PN-Hex) displays promising antimicrobial activity against some cariogenic bacteria, including Streptococcus mutans, which is one of the main causative agents of dental caries. Taken together, our results suggest that this 
extract might be promising for the development of new oral care products. Further studies to isolate and to identify the chemical constituents of PN-Hex are underway.

\section{Acknowledgements}

The authors thank the Brazilian foundations FAPESP (Process 2007/54241-8 and 2016/192729) and CNPq for the financial support and fellowships.

\section{Conflicts of interest}

Author declares there are no conflicts of interest.

\section{Funding}

None.

\section{References}

1. Crevelin EJ, Caixeta SC, Dias HJ, et al. Antimicrobial activity of the essential oil of Plectranthus neochilus against cariogenic bacteria Evid. Based Complement. Alternat Med. 2015;2015(1):102317.

2. Biradar B, Devi P. Quorum sensing in plaque biofilms: challenges and future prospects. J Contemp Dent Prac. 2011;112(6): 479-485.

3. Chandki R, Banthia P, Banthia R. Biofilms: A microbial home. J Indian Soc Periodontol. 2011;15(2):111-114.

4. Wade WG. Characterisation of the human oral microbiome. J Oral Biosc. 2013;55(3):143-148.

5. Marín MJ, Figuero E, González I, et al. Comparison of the detection of periodontal pathogens in bacteraemia after tooth brushing by culture and molecular techniques. Med Oral Patol Oral Cir Bucal. 2016;21(3):e276-e284.

6. Jardim JJ, Alves LS, Maltz M. The history and global market of oral home-care products. Braz Oral Res. 2009;23(supl 1):17-22.

7. Furiga A, Lonvaud-Funel A, Dorignac G, et al. In vitro anti-bacterial and anti-adherence effects of natural polyphenolic compounds on oral bacteria. J Appl Microbiol. 2008;105(5):1470-1476.

8. Barnett ML. The rationale for the daily use of an antimicrobial mouthrinse. J Am Dental Assoc. 2006;137(supl):S16-S21.

9. Choo A, Delac DM, Messer LB. Oral hygiene measures and promotion: review and considerations. Aust Dent J. 2001;46(3):166-173.

10. Kouidhi B, Al Qurashi YM, Chaieb K. Drug resistance of bacterial dental biofilm and the potential use of natural compounds as alternative for prevention and treatment. Microb Pathog. 2015;80(1):39-49.

11. Aguiar GP, Carvalho CE, Dias HJ, et al. Antimicrobial activity of selected essential oils against cariogenic bacteria. Nat Prod Res. 2013;27(18):1668-1672.
12. Melo NI, Carvalho CE, Fracarolli L, et al. Antimicrobial activity of the essential oil of Tetradenia riparia (Hochst.) Codd. (Lamiaceae) against cariogenic bacteria. Braz J Microbiol. 2015;46(2):519-525.

13. Crotti AEM, Aguiar GP, Aguiar DP, et al. Evaluation of the antioxidant activity of some Brazilian medicinal plant extracts. Investigação. 2013;13(1):11-14

14. Aguiar GP, Melo NI, Wakabayashi KAL, et al. Chemical composition and in vitro schistosomicidal activity of the essential oil from the flowers of Bidens sulphurea (Asteraceae). Nat Prod Res. 2013;27(10):920-924.

15. Caixeta SC, Magalhaes LG, de Melo NI, et al. Chemical composition and in vitro schistosomicidal activity of the essential oil of Plectranthus neochilus grown in Southeast Brazil. Chem Biodiv. 2011;8(11):21492157.

16. Melo NI, Mantovani ALL, Oliveira PF, et al. Antischistosomal and cytotoxic effects of the essential oil of Tetradenia riparia (Lamiaceae). Nat Prod Comm. 2015;10(9):1627-1630.

17. Tonuci LRS, de Melo NI, Dias HJ, et al. In vitro schistosomicidal effects of the essential oil of Tagetes erecta. Rev Bras Farmacogn. 2012;22(1):88-93.

18. CLSI. Clinical and Laboratory Standards Institute. Methods for dilution antimicrobial susceptibility tests for bacteria that grow aerobically; approved standard. 2012;M07-A9 32(2).

19. Sarker SD, Nahar L, Kumarasamy Y. Microtitre plate-based antibacterial assay incorporating resazurin as an indicator of cell growth, and its application in the in vitro antibacterial screening of phytochemicals. Methods. 2007;42(4):321-324.

20. Adams R. Identification of essential oils components by gas chromatography/mass spectrometry. IL, USA: Allured Publishing, Carol Stream; 2007. pp.371.

21. Okoye TC, Akah PA, Okoli CO, et al.Antimicrobial and antispasmodic activity of leaf extract and fractions of Stachytarpheta cayennensis. Asian Pac J Trop Med. 2010;3(3):189-192.

22. Cai L, Wu CD. Compounds from Syzygium aromaticum possessing growth inhibitory activity against oral pathogens. J Nat Prod. 1996;59(10):987-990.

23. Santos AO, Ueda-Nakamura T, Dias Filho BP, et al. Antimicrobial activity of Brazilian copaiba oils obtained from different species of the Copaifera genus. Mem Inst Oswaldo Cruz. 2008;103(3):277-281.

24. Saleem M, Nazir M, Ali MS, et al. Antimicrobial natural products: an update on future antibiotic drug candidates. Nat Prod Rep. 2010;27(2): $238-254$.

25. Bougatsos C, Ngassapa O, Runyoro Deborah KB, et al. Chemical composition and in vitro antimicrobial activity of the essential oils of two Helichrysum species from Tanzania. Z Naturforsch C. 2004;59(56):368-372. 